UDC $130.2+159.943 .64$

Gennadiy N. Sadicov, PhD, Professor of the Department of chemistry, ecology and expert technologies

e-mail: sadicov707@gmail.com

Petro G. Kyrienko, PhD, docent of Department of chemistry, ecology and expert technologies

$\boldsymbol{e}$-mail: p.kirienko@khai.edu

Sergii O. Lobov, $\mathrm{PhD}$, docent of Department of chemistry, ecology and expert technologies e-mail: s.lobov@khai.edu

National Aerospace University "Kharkiv Aviation Institute”, Kharkiv, Ukraine

\title{
COMPREHENSIVE CONTENT OF SAFETY OF VITAL ACTIVITY
}

\begin{abstract}
The discipline "Safety of vital activity" emergence as a mandatory subject in schools and universities is related to increased amount and the "quality" of risks generated by scientific and technological progress and appearance of environmental changes within the modern society the technosphere. The safety of vital activity initial foundations is initiated in the family and are subsequently formed and developed in the preschool institution. From the socialization perspective of the individual, the school years are classified as primary school age, adolescence, youth, that characterize socially constructed age periods. This indicates the necessity of creative approaches with including the training programs for safety of vital activity basics. In many cases the training programs and manuals on safety of vital activity programs contains a list of emergencies and the rules of conduct within the occurrence of it, in the absence of the causal analysis, of the medium and long-term consequences of their impact, which is the fundamental in understanding of the essence, predicting and preventing such situations. An alternative to resolving such contradictions can be the introduction of "Ecology" and "Valeology" as mandatory subjects, which appeared concurrently with the "Safety of vital activity", and then disappeared from many educational programs. This range of educational programs represents the organic unity and internalinter connection and focusing increasingly on solving practical problems with concrete results in ensuring the safety of society. The Valeology is the branch of modern preventive medicine aimed to promoting healthy lifestyles. The achievement of Valeology is the separation between health and illness of an intermediate, "third state", when a person is not sick yet, but is no longer healthy. The above characteristics of Ecology and Valeology, which makes visible the organic unity and internal relationship with the "Safety of vital activity". The full pedagogical content of safety and life, and activities in modern conditions of societies existence can be considered as a single set.
\end{abstract}

Key words: pedagogics; risks; scientific and technological progress; valeology; ecology; related; modern society; foundation; primary school age; training programs; fundamental in understanding of the essence; vital activity basics; medicine

(C) G.N. Sadicov, P.G. Kyrienko, S.O. Lobov, 2020 


\section{Г.М. Садіков, П.Г. Кирієнко, С.О. Лобов}

Національний аерокосмічний університет ім. М.Є. Жуковського “Харківський авіаційний інститут”, м. Харків, Україна

\section{КОМПЛЕКСНИЙ ЗМІСТ БЕЗПЕКИ ЖИТТСДІЯЛЬНОСТІ}

Анотація. Поява навчальної дисиипліни «Безпека життєдіяльності» як обов'язкового предмета в школах та університетах пов'язана із збільшенням кількості та «якості» небезпек, породжених науково-технічним прогресом, $i$ виникненням зміненого середовища проживання сучасного суспільства техносфери. Початкові основи безпеки життєдіяльності закладаються в сім'ї, а згодом формуються та розвиваються в дошкільному закладі. 3 точки зору соиіалізаиії особистості икільні роки класифікуються як молодший икільний вік, підлітковий вік, молодість - характерні вікові періоди. Це обумовлюе необхідність застосування творчих підходів щодо включення навчальних програм з безпеки основ життєдіяльності. У багатьох випадках навчальні програми та посібники з безпеки програм життєдіяльності містять перелік надзвичайних ситуачій та правила поведінки в разі їх виникнення, за відсутності причинного аналізу, середньо- та довгострокових наслідків їх впливу, що $\epsilon$ фундаментальним у розумінні сутності, прогнозуванні та запобіганні таким ситуачіям. Альтернативним підходом 3 метою вирімення таких суперечностей може бути введення "Екології" та "Валеологї" як обов'язкових предметів, які вже з'являлись у шкільній програмі одночасно з "Безпекою життєдіяльності", але потім зникли з багатьох освітніх програм. Цей комплекс освітніх програм становить органічну иілісність та має внутрішній взаємозв'язок $i$ все більше зосереджується на вирішенні практичних проблем із конкретними результатами у забезпеченні безпеки суспільства. Валеологія - ие розділ сучасної профілактичної медицини, спрямований на пропаганду здорового способу життя. Досягненням валеології $\epsilon$ виділення між здоров'ям та хворобою проміжного, „,третього стану”, коли людина ще не хвора, але вже не здорова. Комплекс означених дисииплін є основою формування інстинкту безпеки життєдіяльності в умовах постійного збільшення кількості небезпек, зумовлених науково-технічним прогресом.

Ключові слова: педагогіка; ризики; науково-технічний прогрес; валеологія; екологія; сучасне суспільство; фундамент; молодший шкільний вік; навчальні програми; основи життєдіяльності; ліки

\section{Introduction}

The appearance of the subject "Safety of vital activity" in schools and universities as a compulsory discipline is associated with an increase in the number and "quality" of dangers generated by scientific and technological progress (STP) and the appearance of a modified living environment of modern society - the technosphere. The history of the emergence and development of discipline begins in the late $80 \mathrm{~s}$, early 90 s of the last century, the period is relatively short, 30 years. During this period, the discipline gained accelerated development, which allows us to consider it as a social order of the society to anticipate and prevent the dangers of STP. 


\section{Main part}

The subject "Basis of safety of vital activity" discipline in its official purpose is studied in institutions of primary, general, secondary and vocational education and is aimed at developing a safety culture, preparing students for safe behavior in everyday life, in dangerous situations, including in emergency situations. An official status remark is such a definition as the development of a safety culture. For the first time, this definition appeared in 1986 in the process of analyzing the causes and consequences of the Chernobyl accident, and the term was introduced by the International Nuclear Safety Advisory Group in the "Final Report of the Meeting to Review the Causes and Consequences of the Chernobyl Accident". The report showed that the lack of a safety culture was one of the reasons for the Chernobyl tragedy. The International Atomic Energy Advisory Group under the IAEA Director General has proposed the following definition of this concept. Safety culture is such a set of characteristics and features of organizations' activities and the behavior of individuals that establishes that the problems of the nuclear power plant, as having the highest priority, are given attention, determined by their significance. Despite the complex of measures taken in the field of life safety, there is no steady tendency to reduce human losses and material damage from accidents, catastrophes, natural disasters, various dangerous situations in everyday life, the social sphere, and in production. At present, it has become obvious that the process of ensuring safety of vital activity cannot be reduced only to such a traditional, sufficiently approved direction as the formation of knowledge and skills among the population. The practice, results of psychological, pedagogical, and social studies show that, largely, the success of activities in any field depends, in addition, on the emotional and value attitudes of people, their motives for behavior, personal and professional qualities and abilities, confidence in the need and effectiveness of activities. Experience shows that the activity to increase the reliability of technical objects, create algorithms for their safe management, develop perfect means and methods of protection against emergency situations of a natural, technogenic and biologicalsocial nature is ineffective without taking into account the human factor [1].

The long-term period of using the safety culture did not provide significant results in this problem. Currently, the concept of culture is used in various areas of life and society (the culture of microorganisms, tissue culture, production culture, physical culture, culture of consumption of alcoholic beverages, etc.). The concept of culture has become a multifaceted, amorphous form with an indefinite social content. The methodological content of the subject of safety of vital activity at school should be more specific and focused, ensuring the formation of a worldview of security. Worldview - a system of principles, views, values, ideals and beliefs that determine the direction of activity and attitude to the reality of an individual, class or society as a whole. The presence of beliefs is a distinctive feature in determining the worldview. Their presence is formed by the character traits and mood of a person based on individually - typological personality traits: temperament, character, volitional qualities, abilities, emotional content, level of motivation. Beliefs combined with personal characteristics of a person allow him to take an active life position in the struggle for his views, ideals and beliefs, i.e. for his worldview.

Worldview, unlike culture, has clearly defined boundaries and does not allow their violation. Another important methodological circumstance when compiling subject for the basics of safety of vital activity at school is that the concept of culture 
involves the transfer of experience and traditions to the next generation, which are formed and consolidated in public life as a result of a long time period, but constantly increasing growth rates of scientific and technological progress to the lack of continuity of generations. At present, the experience of the previous generation is not transmitted, and in some cases is not accepted by the next. Therefore, the culture of life safety as the transfer of experience, customs, traditions, skills from generation to generation is not necessary. Under these conditions, new methodological approaches and organizational decisions are needed at the level of worldview beliefs $[3,4,5]$.

From the standpoint of personality socialization, school years, which are divided into primary school age, adolescence, youth, are characterized by socially determined age periods. The periods of "youthful maximalism", when white must necessarily be only white, black only black and various transitional states are unacceptable, are most favorable for the formation of a worldview of security, they can be stable and unchanged in subsequent life. In adulthood, they can be corrected due to economic, socio-political, national and many other circumstances, processes, phenomena, but the worldview positions formed in the school years are more stable. This shows the need for a creative approach when creating training programs for the basics of vital activity safety. In most cases, training programs and manuals on vital activity safety programs contain a list of emergencies and rules of conduct when they occur, in the absence of a causal analysis, the medium and long-term consequences of their impact, which is fundamental in understanding the essence, predicting and preventing these situations.

The official definition of safety pedagogy is a scientific direction on the laws governing the development of a person's life experience in the field of life safety. Life experience is the basis of professionalism, pedagogical mastery, it is both a source, and a means, and the result of a person's spiritual development [7]. A person's life experience is an analysis, synthesis, and generalization of it through trial and error.

Professionalism in the context of the growing quantity and quality of scientific and technological risks due to the constantly increasing power supply and the emergence of energy-intensive technologies requires a different methodological approach to the content of education aimed at ensuring safety. Since when resolving issues of ensuring the safety of activities, the issues of the economic content of this activity, profitability, productivity, and other economic indicators are primarily resolved, and secondarily, the environmental impact of this activity and long-term consequences. Given the existing power supply, any activity leads to the disruption or destruction of evolutionarily developed ecosystems, causing the emergence of new dangers that can be much more dangerous than the primary ones.

Under these conditions, the task of safety pedagogy is to find a compromise, a middle ground between the economic content of activities and the environmental content of environmental protection. The search for compromises in the preparation of life safety training programs will constantly increase, as to stop the development of scientific, technical progress is practically impossible, and to tear modern society from the benefits of civilization, which is defined, as a consumer society is not a real task. An alternative in eliminating these contradictions may be the introduction of such subjects as "Ecology" and "Valeology" as compulsory educational disciplines, they appeared simultaneously with "Safety of vital activity", but later on, they safely disappeared from many curricula. 
The introduction of these subjects as mandatory will allow us to consider the safety of vital activity as a discipline in a methodological plan, which contains not only a list of dangers and rules of behavior in these conditions, but a causal analysis of the occurrence of dangers is given to the methodological content of life safety. This is a significant addition to the safety of life of society as a whole, because allows you to predict, make appropriate decisions and carry out preventive work to eliminate the danger, both in specific conditions and in the long run.

This set of academic disciplines represents organic unity and internal interconnection and is aimed mainly at solving practical problems with specific results in ensuring the safety of society. The relevance of this complex will constantly increase as the number and "quality content" of the dangers posed by scientific and technological progress increase. Currently, the greatest number of dangers is associated with the emergence of environmental problems, a time for which the environmental crisis from abstraction has acquired quite real outlines. The development and growth of environmental problems depends on changes in the relationship of human society with the environment. Modern society is not able to abandon the innovations of scientific and technological progress, their quantity and quality will increase from year to year.

Under these conditions, the main means of protection from the environmental problems of modern progress is to know, understand and foresee them during the period of education of vital activity safety, at all its stages, which should be based on environmental perception, environmental thinking, environmental awareness and, ultimately, ecological worldview. This justification is most relevant for technical educational institutions, as the main suppliers of technocracy and, as an alternative to technocracy, the training of environmental engineers, and the most sought-after category of professionals for this period and for the future [2]. The ecological problems of modern society are based on the contradiction between the biological nature of man and his social essence, between the existing habitat of modern man, the technosphere and the biosphere created by many millions of years of evolution. The initial definition of ecology, a section of biology that studies the relationship of animals, plants, microorganisms with each other and with the environment. In the original definition, there is no mention of a person. In the modern definition, at the moment, ecology must be considered as a comprehensive scientific direction that generalizes, synthesizes data from the natural and social sciences about the natural environment and its interaction with man and human society. The goals and objectives of modern ecology have changed significantly, their content is aimed at solving the following environmental problems: the study of the laws of life organization, including in connection with the anthropogenic impact on natural systems, the creation of a scientific basis for the rational exploitation of biological resources, the prediction of changes in nature arising under the influence human activities; determination of permissible limits of human impact on the environment, conservation of the living environment of living organisms, including humans; development of recommendations for the development of human society.

The main theoretical and practical task of ecology is to reveal the general laws of the organization of life and, on this basis, to develop the principles of rational use of natural resources under the conditions of an ever-increasing human influence on the biosphere [8].

A comparative analysis of the initial definition of ecology and a modern interpretation, with its theoretical and practical tasks, shows the organic unity and 
interconnection of ecology and the vital activity safety at the current level of development of society.

The main provisions of the theory of life safety are presented in the form of a number of axioms. One of the axioms implies the following: in addition to positive properties and results, man-made technical means, equipment and technologies have the ability to generate hazards, this axiom is considered the main postulate of vital activity safety: any human activity is potentially dangerous [9]. The conclusion from this tough and categorical conclusion consists in the mandatory inclusion in the life safety of the environmental problems of modern society, the number of which is constantly increasing and their qualitative content is constantly changing.

The inclusion of environmental problems in the safety of life allows us to predict and, through foresight, to carry out preventive measures to eliminate potentially dangerous anthropogenic activities, ensure environmental safety and create conditions for rational nature management.

On the basis of the above-mentioned tasks of modern ecology, a completely logical question arises whether scientific and technological progress can be considered progress, the progress of technology is obvious, but it leads to a change in the main factors of life support of air, water, soil and, as a result, the emergence of diseases that are classified as "diseases of civilization". According to experts of the World Health Organization, the following social risk factors in the development of diseases of civilization are distinguished: irrational, unbalanced diet, sedentary lifestyle (physical inactivity, hypokinesia), high levels of nervous tension (various types of stress), bad habits, lack of education, low general culture and lack of knowledge about a healthy lifestyle, lack of behavior, communication. Diseases of civilization have a more precise definition - lifestyle diseases, they can be considered as retribution for the benefits of civilization. They are directly related to the environmental problems of society, such as cause and effect, environmental change - cause, disease - the result of these changes, the logical conclusion of this connection, the health of society depends on rational protection and environmental protection. The danger of civilization's diseases for the life of society consists in the fact that their number is constantly increasing and the largest percentage of occurrence occurs in countries with a developed economy and industry, a high level of security and a wealth of the population.

"Valeology" is engaged in the study of lifestyle diseases, among the various conflicting definitions of valeology as a scientific discipline, one can be identified that corresponds to the topic of this article. Valeology is a section of modern preventive medicine aimed at creating a healthy lifestyle (HLS) in people. This definition is fully consistent with the comprehensive content of life safety aimed at protecting public health in modern conditions. The achievement of valeology is the separation between health and illness of an intermediate, "third state", when a person is not sick yet, but is no longer healthy. The category of people in this state is constantly growing under the influence of a changing environment, lifestyle, and the benefits of the civilization of scientific and technical progress.

The pedagogical valeology has been formed from valeology, and which studies the issues of training and education of a person who has a solid life orientation to health and a healthy lifestyle at various age stages of age development. For this period, this branch of valeology is developing most dynamically, which is due to the following circumstances: the need of society for urgent measures to improve a person through the education of his health culture; the problem of the negative 
impact of the educational environment on children's health, the relative cheapness of the introduction and implementation of valueological programs for improving the population. The basic concepts of pedagogical valeology are valeological education, valeological education, valeological education, valeological worldview. Currently, the following basic concepts can be defined that characterize valeology: Valeology is a direction based on the idea of the genetic and functional reserves of the systems of the human organism and the human organism as a whole, ensuring the stability of psychophysiological and sociocultural development and maintaining human health under the influence of changing ones conditions of the external and internal environment [10].

\section{Conclusions}

1. The above-mentioned characteristics of "Ecology" and "Valeology" show organic unity and internal relationship with "Safety of vital activity", the full content of safety and life, and activities in modern conditions of society's existence has to be considered in a single complex.

2. The complex of these disciplines is the basis for the formation of the life safety instinct in the face of a constant increase in the number of dangers of scientific and technological progress.

\section{REFERENCES}

1. Durnev, R.A. (2006). K voprosu o culture besopasnosti dgisnedeyatelnosti. Tehnologii grazdanskoi bezopasnosti, (2). (in Russian)

2. Sadikov, G.N., Kobrin, V.N. (2006). Ingener-ekolog - professiya socialnogo sakasa. Gumanitarni chasopis, (3). (in Russian)

3. Sadikov, G.N. (2013). Tceli i sadachi besopasnosti dgisnedeyatelnosti - formirovanie mirovosreniya besopasnosti. Gumanitarni chasopis, (2). (in Russian)

4. Sadikov, G.N. (2014). K voprosu otnositelnosti novisni ponyatiya «kultura besopasnosti dgisnedeyatenlnosti». Gumanitartni chasopis, (2). (in Russian)

5. Sadikov, G.N. (2015). Ierarchiya potrebnostey A. Maslou ne sootvetstvuet biologicheskoi prirode cheloveka. Gumanitarni chasopis, (2). (in Russian)

6. Sadikov, G.N. (2017). Besopasnost dgisnedeyatelnosti - religiya XXI veka. Gumanitarni chasopis, (3/4). Retrieved from: https: // spiritual. culture. acadmic. ru / 808 (in Russian)

7. Retrieved from: https: // students - library. com /ua/read//9810 - ekologiya

8. Retrieved from: https: // studfiles. net / preview / 6468044

9. Retrieved from: www. Grandors. ru / college /medicina/ valeologia.

The article was received 09.04.2020 and was accepted after revision 17.07.2020

\section{СПИСОК ЛІТЕРАТУРИ}

1. Дурнев Р.А. К вопросу о культуре безопасности жизнедеятельности / Р.А. Дурнев / Технологии гражданской безопасности. - 2006. - № 2.

2. Садиков Г.Н. Инженер-эколог - профессия социального заказа / Садиков Г.Н., Кобрин В.Н. // Гуманітарний часопис - Харків, 2006, № 3.

3. Садиков Г.Н. Цели и задачи безопасности жизнедеятельности - формирование мировоззрения безопасности / Г.Н. Садиков // Гуманітарний часопис. - Харків, 2013 № 2 . 
4. Садиков Г.Н. К вопросу относительности новизны понятия «культура безопасности жизнедеятельности». / Г.Н. Садиков // Гуманітарний часопис - Харків, 2014, - №2.

5. Садиков Г.Н. Иерархия потребностей А. Маслоу не соответствует биологической природе человека / Г.Н. Садиков // Гуманітарний часопис - Харків, 2015, - №2.

6. Садиков Г.Н. Безопасность жизнедеятельности - религия XXI века. / Г.Н. Садиков Гуманітарний часопис // Харків, 2017, № 3/4.7. https: // spiritual. culture. acadmic. ru / 808/ - Жизненный опыт.

7. https: // students - library. com /ua/read//9810 - ekologia

8. https: // studfiles. net / preview / 6468044

9. www. Grandors. ru / college /medicina/ valeologia.

Стаття надійшла до редакиії 09.04.2020 і прийнята до друку після рецензування 17.07.2020

\section{Садіков Геннадій Миколайович}

доктор біологічних наук, професор кафедри хімії, екології та експертизних технологій Національного аерокосмічного університету ім. М.Є. Жуковського "Харківський авіаційний інститут"

Адреса робоча: 61070 Україна, м. Харків, вул. Чкалова, 17

e-mail: sadicov707@gmail.com

\section{Киріснко Петро Григорович}

кандидат технічних наук, доцент кафедри хімії, екології та експертизних технологій Національного аерокосмічного університету ім. М.Є. Жуковського “Харківський авіаційний інститут"

Адреса робоча: 61070 Україна, м. Харків, вул. Чкалова, 17

e-mail: p.kirienko@khai.edu

\section{Лобов Сергій Олександрович}

кандидат технічних наук, доцент кафедри хімії, екології та експертизних технологій Національного аерокосмічного університету ім. М.С. Жуковського “Харківський авіаційний інститут"

Адреса робоча: 61070 Україна, м. Харків, вул. Чкалова, 17

e-mail: s.lobov@khai.edu 